\title{
A trama do nu
}

Clarissa Macedo ${ }^{1}$

Abandonei as roupas que eu tinha.

No meu gesto cabe agora

a paixão de muros encarnados.

As roupas que tive me privaram de ser nua

mas não cobriram a serenidade

do curvo rastro de minha pele

pele-máquina, vazia de mãos de homem.

Meu vestígio é minha nudez

que se oferenda e que se abre

diante de um largo armário

(cheio de escudos que vingam faltas)

meu vestígio é minha nudez

que se rasga

diante da possibilidade de não ser pássaro.

\section{Das razões do ofício}

Eu não sei fazer poemas

\footnotetext{
${ }^{1}$ Doutoranda em Literatura e Cultura do PPGLitCult pela UFBA.
} 
mas me dilacero

a cada verso que escrevo.

\section{Corte}

Há um leste na lua

de concupiscência:

na primeira braçada

a luz emana sua haste

na segunda margem

as pétalas se abrem

ao espaço, e o rio

que corre no dorso

de um lago

se petrifica e vaza

na terceira lenda

santifica-se

o silêncio dos tempos

e no minuto eterno

nasce uma poesia 


\section{Darandina}

revist e I e t r ón i c a

primitiva -

aquela que contém

o código de todos

os tormentos. 